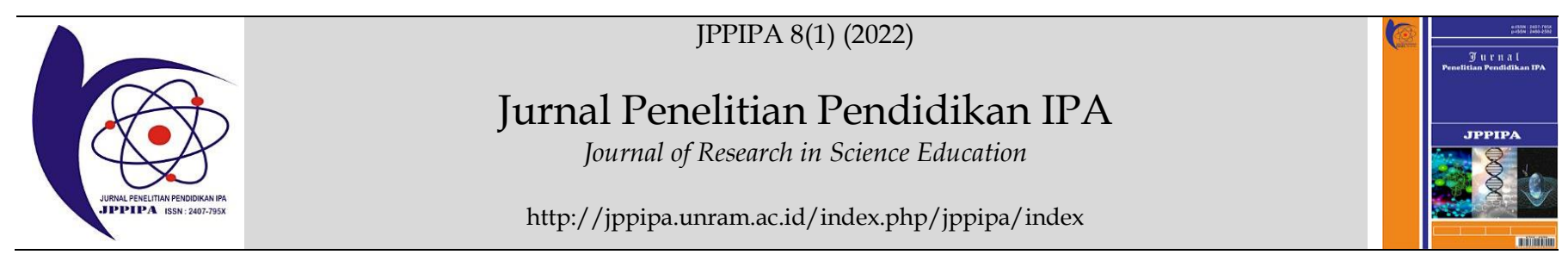

\title{
Analysis of Science Learning Achievement Based on Parents' Socio- Economic Status and Students' Interest in Science Learning
}

\author{
Nunung Setiati ${ }^{*}$, Jumadi ${ }^{1}$ \\ ${ }^{1}$ Physics Education, University of Yogyakarta, Special Region of Yogyakarta, Indonesia.
}

DOI: $\underline{10.29303 / \text { ippipa.v8i1.1249 }}$

\section{Article Info}

Received: December 19, 2021

Revised: January 16, 2022

Accepted: January 19, 2022

Published: January 31, 2022

\begin{abstract}
This study aims to analyze science learning achievement based on socio-economic status and students' interest in learning science. This research is a qualitative research. The qualitative research used is descriptive qualitative research. The data were obtained from the scores given by the previous science teacher. Furthermore, data were collected by using indepth interviews and participatory observation to data sources. The collected data was then validated by triangulation technique. Triangulation carried out in this study includes triangulation of techniques and triangulation of sources. The collected data is then analyzed using the Miles and Huberman model. In this technique, there are four stages of analysis, namely the stage of data collection, data reduction, data display, and conclusion. Based on the results of the study, it was found that the economy of parents has a very important role in the achievement of students in science learning. This happens because students need smartphones as a facility in daring to learn from home and parents must provide them. In addition, learning interest during the covid-19 pandemic is also very important to foster a sense of learning so that students' learning achievement can increase.
\end{abstract}

Keywords: Learning achievement; Socio-economy; Science learning; Study online; Covid-19

Citation: Setiati, N., \& Jumadi, J. (2022). Analysis of Science Learning Achievement Based on Parents' Socio-Economic Status and Students' Interest in Science Learning. Jurnal Penelitian Pendidikan IPA, 8(1), $296-301$. https://doi.org/10.29303/ippipa.v8i1.1249

\section{Introduction}

Education is the embodiment of human culture which is full of development (Al-Tabany, 2014). The era that continues to develop requires everyone to be able to follow these developments. At this time the Covid-19 pandemic occurred, causing educational institutions to conduct distance education at this time (Nwagwu, 2020). The current era requires students to study from home because of the COVID-19 pandemic.

The current era is an era where there is a covid-19 pandemic that causes direct learning at school to become learning at home. This is in accordance with directives from the government that every teaching and learning that takes place in schools must be done at home with an online learning system (Basar, 2021). Online learning is learning that is carried out remotely through the help of the internet network and other supporting tools such as smart phone (Arizona, et al., 2020).

A very significant difference during the learning process of students from usual, will affect the sharpening of the way students think about their learning. In the learning process the teacher is not able to provide the overall material to students because they have to learn from home. However, students are asked to understand the material without direct interaction from the teacher. This causes learning achievement is not given optimally (Pillay, et al., 2007). In addition to the way students think, their learning achievement in science during the COVID-19 pandemic is also influenced by their interest in learning. It often happens today those students tend to be lazy to learn because they do not interact with the school environment,

\footnotetext{
*Email: nunungsetiati.2021@student.uny.ac.id
} 
especially in learning science. This happens because of the lack of interest in learning from students. Even though during the COVID-19 pandemic, interest in learning is very much needed to face this distance learning (Bringula, et al., 2021).

Umar (2015) suggests that learning achievement is a child's behavior in studying learning at school which is expressed by scores, which are obtained from test results regarding a number of subject matters. Winkel, (2004) learning achievement is a mental process that leads to assignments, knowledge, or attitudes, all of which are acquired, stored, and implemented so as to cause progressive behavior. Children's learning achievement at school can be seen from student learning outcomes in the form of daily test scores, midsemester tests, or end-of-semester tests (Subagia \& Wiratma, 2016). Student learning achievement in online learning remains the same, which is seen from the daily test scores, mid-semester tests, and end-semester tests. But the difference is only in how students get their learning achievement. Students must be able to understand the material even without direct interaction from the teacher, and the teacher is not able to provide the material as a whole to students. This will affect student learning achievement.

This research was conducted because it was strengthened by previous research, namely, research conducted by Syafa' ati, et al., (2021) entitled Analysis of Student learning achievement when studying online during the covid 19 pandemic. The result of this study is that student learning achievement can be achieved due to external factors, namely the assistance, assistance, and guidance of parents in online learning at home, and also because of the application of effective and efficient learning methods so that students learn more easily. Further research was carried out by Wiradarma, et al., (2021) with the results of the study, namely interest in learning has a positive relationship with learning outcomes.

\section{Method}

This research uses qualitative research. The qualitative research used is by using a descriptive approach method. The descriptive approach method is used to investigate, then find something from the results of the investigation, after that, describe the results of the investigation, and then, explains in detail about something that cannot be measured and explained through a quantitative research approach (Saryono, 2010).

Learning achievement data is obtained from assignment grades, daily test scores, mid-semester grades, and end-of-semester grades. The data was provided by a science teacher who had recaptured the students' scores. Furthermore, after obtaining learning achievement data, namely data collected by in-depth interviews and observations that have been made. Data were collected using interview guides and observation guidelines which were open and could develop according to the answers from research informants. The interview is a method of data collection that requires direct communication between investigators with the subject or respondent.

Interviews usually involve one-sided questions and answers which are carried out in a systematic and grounded on research objectives (Riyanto, 2011). The data comes from various sources, namely school principals, teachers, administrative staff, village officials, parents, and children who are the unit of observation of this research. The data sources were selected by cluster random sampling.

The collected data was then validated by the triangulation technique. Triangulation carried out in this study includes triangulation of techniques and triangulation of sources. In technical triangulation, the data generated from the interview technique is checked with the data generated from the observation technique. Meanwhile, in source triangulation, data obtained from one source is checked with data from other sources. Only data that are confirmed to be valid will be recognized as data for this research.

The data that has been collected is then analyzed using the interactive data analysis technique of Miles and Huberman's theory. In this technique, there are four stages of analysis, the first stage is to collect data, the second stage is to reduce the data, the third stage is to present the data and the last stage is to draw conclusions. The data collected was then validated by triangulation. Data that is not relevant to the research and data that is not validated is then reduced, and the validated data is then displayed. Finally, the data displayed is concluded in the conclusion stage.

\section{Result and Discussion}

This study aims to analyze science learning achievement based on the socioeconomic status of parents and students' interest in learning science. This research uses qualitative research. The qualitative research used is by using a descriptive approach method.

The results of this study consisted of observations and interviews conducted at schools and at students' homes. Science learning achievements of students are obtained from the assessment data of science teachers during the covid-19 pandemic. Based on the data obtained from the science teacher, students are grouped with high learning achievement, medium learning achievement and low learning achievement. The data 
was obtained based on daily, mid-semester and semester test scores during online learning from home. An overview of the socioeconomic status of Class VII A MTS students Haqqul Yaqien NW Sayang-Sayang during the covid-19 pandemic

Socio-economic status

Socio-economic status usually includes the social status given by the community, economic status, parents' occupations, and many others related to the socioeconomic status of people (Tomul, et al., 2021). So that one of the most decisive factors for differences in student achievement is the education level of parents and the highest family income (Chevalier \& Lanot, 2002).

Adequate parental income during the COVID-19 pandemic will support children's growth and development because parents can provide for all the children's needs, both primary and secondary. Based on the results of the study, it is said that when the family's economic income increases, the learning achievement of children can also increase, and generally children from underprivileged families have lower learning achievements (Chevalier \& Lanot, 2002). so that the family can be the main determining factor that makes a difference in student achievement. Therefore, it is reported that the role of socioeconomic status and family culture can be one of the factors so that student achievement varies (Yamamoto \& Holloway, 2010). Therefore, it can be seen how parents are involved in the learning achievement of students (Christenson, 2004).

Socio-economic status is generally divided into three levels. Three levels based on classification are social status with high economy, social status with the moderate economy, and social status with the low economy. Socio-economic status of parents of students Class VII a MTS Haqqul Yaqien NW Sayang-Sayang, they tend to be of medium and low socioeconomic status, as the results of the observation show that:

"Based on the results of observations made at the school and sub-district of Sayang-Sayang, the researcher found that the parents of class VII A students at MTS Haqqul Yaqien NW Sayang-Sayang mostly work as laborers and traders" (observation results November 26, 2021).

Based on these observations, it shows that the socioeconomic status of the parents of class VII A students of MTS Haqqul Yaqien NW Sayang-Sayang belongs to the lower middle socioeconomic status because the majority of parents of students of class VII A MTS Haqqul Yaqien NW Unfortunately are entrepreneurs, traders, craftsmen, and laborers.
Factors that affect Socio Economic Status

1. Work

Parents of Students with High Learning Achievement

Based on the results of interviews conducted with one of the informants from parents of students with high learning achievement said that:

"I work as a corvette craftsman. Usually, before the Covid-19 pandemic, I was able to export corvette handicrafts such as chairs, couches, cupboards, tables, and so on abroad, and during this covid-19 pandemic, the export of corvettes was limited, and sometimes it didn't sell for a day." (Excerpt from Abdullah interview).

Parents of students with moderate learning achievement.

"My job is a merchant. Usually, I sell in the market every day. During this COVID-19 pandemic, I felt a change in my merchandise because usually, my merchandise could run out, but during this pandemic, I still had half of my merchandise left. It could be that people are also experiencing economic difficulties at the moment so there is a decrease in buyers." (Excerpt from Muptadil interview).

\section{Parents of students with low academic achievement}

"During the COVID-19 pandemic, my job was as a laborer. This is because work is very difficult during this covid-19 pandemic." (Excerpt from Mubtadin interview).

\section{Income}

Income can be defined as salaries, wages, profits, rent and any flow received. Sources of income are received in the form of workers' compensation, government benefits, receivables, and so on. There are two terms in income, namely absolute income and relative income. Absolute income is a person's income which is only measured in one variable, namely money. Meanwhile, relative income is income seen from two variables, namely money and time. Income is a measure that is generally used to measure a person's socioeconomic status because it is relatively easy to know.

\section{Parents of students with high learning achievement}

Based on the results of interviews conducted with one of the informants from parents of students with high learning achievement said that:

"My current income is around 2 million more per month, I use it to meet my daily basic needs and the rest I use for other needs and I save. In addition, to buy children's needs for school needs such as books and stationery, I can fulfill them and during the pandemic I give my cellphone because I use the cellphone for work. Besides that, for quota purposes, I use Wi-Fi." (Excerpt from Abdullah interview). 
Parents of students with moderate learning achievement

"My income is uncertain from sales every day, sometimes 1 million per month, sometimes 2 million per month, but during the covid-19 pandemic, my income is at most 1 million per month. This happened because of the COVID-19 pandemic because the economy was difficult. I usually use the proceeds from my sales to fulfill my daily basic needs, if there is leftover, I can buy my children's school needs. In addition, during the covid 19 pandemic, my child of course needs a smartphone for school because now he is studying at home. The smartphone that I bought was only for my sister, so I had to use a smartphone instead because her sister also went to school. (Excerpt from Muptadil interview).

\section{Parents of students with low academic achievement}

"My job is a laborer, of course, my income is uncertain. Sometimes there is no income per day, so you have to go into debt. Especially during the Covid-19 pandemic, work is very difficult. I did get help from the government, but the money was for me to pay off my debt. Of course, the income I get is only to fulfill my daily basic needs and that is still not enough. Sometimes I can't even fulfill my children's school needs, so during this covid-19 pandemic, my child should need a smartphone, but I can't afford a smartphone because I don't have enough finances. My child usually sometimes studies at his friends' houses during this covid-19 pandemic because there are no smartphones and quotas. (Excerpt from Mubtadin interview).

\section{Interest in learning science students during the covid-19 pandemic}

Interest in learning is a relatively permanent tendency to pay more attention and remember continuously accompanied by a sense of satisfaction shown through enthusiasm, participation and activity in achieving learning goals (Slameto, 2003).

The learning interest of class VII A students of MTS Haqqul Yaqien NW Sayang-sayang, we can classify them into three levels, namely high, medium, and low. Learning interest of class VII, A students of MTS Haqqul Yaqien NW Sayang-sayang, there is a tendency for moderate and low interest in learning, as the results of in-depth interviews with students found that:

Learning interest of students with high learning achievement

Based on the results of interviews conducted with one of the informants of students with high learning achievement said that:

"I have loved studying science since I was in elementary school. I think science is a lesson related to everyday life. Currently learning science is not in school but online learning at home. Learning science during the covid-19 pandemic was not an obstacle for me because I could learn independently at home with the help of my sister. I did not find it difficult when study online from home because the facilities provided by my parents were complete, starting from a smartphone and Wi-Fi. Moreover, having a smartphone can help me to find answers to the assignments given by the teacher. This of course makes it easier for me to learn because there are no obstacles in learning." (Excerpt from Indra interview)

Learning interest of students with moderate learning achievement

Based on the results of interviews conducted with one of the informants of students with moderate learning achievement said that:

"During this COVID-19 pandemic, learning science must learn online from home so that teachers teach via smartphones. At first, I liked to learn science, but the longer I studied science during the covid-19 pandemic, it caused me not to understand learning science because I did not understand the teacher's explanation when the teacher explained through a smartphone. In addition, the limited facilities make the enthusiasm for learning science decrease. This is because the smartphone that is used must alternate with my brother. This makes my interest in learning decrease." (Excerpt from Ari interview)

\section{Learning interest of students with low learning achievement}

Based on the results of interviews conducted with one of the informants of students with low learning achievement said that:

"I don't like science because science is the most difficult subject for me. Currently, learning has to be done from home, so I initially didn't like science, which made me dislike science even more because I didn't understand the teacher's explanation. This is also the result of me rarely going to school when studying online because I don't have a smartphone to participate in online learning. This of course makes me lazy to join online learning. Sometimes I don't do assignments because I don't know there is work at the time." (Excerpt from Aulia interview)

Based on these observations and interviews, it can be seen that the Covid-19 pandemic has had an impact on various things, including changes in formal education patterns. These changes have an impact on the difficulties experienced by students when undergoing new learning patterns. When learning is done at home (study from home), students not only need writing instruments but also need a smart phone or laptop because, during the Covid-19 pandemic, students learn online using a smartphone or laptop. These differences will of course affect learning achievement. In accordance with the research that has been done, learning achievement can be influenced by the socioeconomic status of parents and student's interest in learning science. 
The socioeconomic status of the parents is obtained from the work of the parents and the income of the parents. Income is seen based on the work of parents, the better the work of parents, the greater the income obtained, and the lower the work of parents, the smaller the income. During the COVID-19 pandemic, parental income was very influential in providing learning facilities during online learning because during the COVID-19 pandemic, not only writing instruments were needed for schools, students also needed smart phones for the learning process to take place. Based on the results of the study, it was found that the greater the income of parents, the more parents can meet the needs of their children's facilities in the school. This of course can make it easier for students to follow the learning process because of the facilities.

The results of this study are also strengthened by previous research. the role of socioeconomic status has been examined within the framework of the Turkish education system in the context of educational equality, revealing a significant positive relationship between socioeconomic status and achievement (Bellibaş, 2016). Socio-economic status plays an important role in educators because there is an influence between socioeconomic status and student learning achievement (Kalaycıoğlu, 2015). So that there is a positive influence between learning achievement and socioeconomic status (Tomul \& Savasçi, 2012). therefore socioeconomic status is a strong component in student learning achievement (Ersan et.al., 2020).

Based on the results of observations and interviews as well, it was found that interest also affects science learning achievement during the covid-19 pandemic. Interest in learning science is the desire and enthusiasm of students in participating in science learning. Interest in learning science is of course very influential on student learning achievement because the interest in learning science it will encourage students to take part in learning well. Based on the results of observations and interviews, it was found that the higher the request to learn science, the better the learning achievement.

The results of this study are also strengthened by previous research. There is an influence of interest in learning on physics learning achievement. This influence significant with the obtained sig value of 0.000 which is smaller than 0.05 . Based on this, the better the student's interest in learning, the more also good physics learning achievement (Astuti, 2015). so that interest in learning is one of the main components in science learning both in the short and long term (Bathgate \& Schunn, 2017). This is because without an interest in learning science it can make it difficult for students to get the maximum value in learning science so that it can affect science learning achievement (Awang, 2015).

\section{Conclusion}

Based on the results of the study, it was found that the economy of parents has a very important role in the achievement of students in science learning. This happens because students need smartphones as a facility in daring to learn from home and parents must provide them. In addition, learning interest during the covid-19 pandemic is also very important to foster a sense of learning so that students' learning achievement can increase.

\section{References}

Al-Tabany, I.B.T. (2014). Mendesain Model Pembelajaran Inovatif, Progresif, dan Kontekstual. Jakarta: Prenadamedia Group.

Arizona, K., Abidin, Z., \& Rumansyah, R. (2020). Pembelajaran online berbasis proyek salah satu solusi kegiatan belajar mengajar di tengah pandemi covid-19. Jurnal Ilmiah Profesi Pendidikan, 5(1), 64-70. DOI: https://doi.org/10.29303/jipp.v5i1.111.

Astuti, S. P. (2015). Pengaruh kemampuan awal dan minat belajar terhadap prestasi belajar fisika. Formatif: Jurnal Ilmiah Pendidikan MIPA, 5(1). http://dx.doi.org/10.30998/formatif.v5i1.167.

Awang, I. S. (2015). Kesulitan Belajar IPA Peserta Didik Sekolah Dasar. VOX EDUKASI: Jurnal Ilmiah Ilmu Pendidikan, 6(2), 108-122. DOI: https://doi.org/10.31932/ve.v6i2.106.

Basar, A. M. (2021). Problematika Pembelajaran Jarak Jauh Pada Masa Pandemi Covid-19: (Studi Kasus di SMPIT Nurul Fajri-Cikarang Barat-Bekasi). Edunesia: Jurnal Ilmiah Pendidikan, 2(1), 208-218. DOI: https://doi.org/10.51276/edu.v2i1.112.

Bathgate, M., \& Schunn, C. (2017). Factors that deepen or attenuate decline of science utility value during the middle school years. Contemporary Educational Psychology, 49, 215-225. https://doi.org/10.1016/j.cedpsych.2017.02.005.

Bellibaş, M. S. (2016). Who are the most disadvantaged? Factors associated with the achievement of students with low socioeconomic backgrounds. Educational Sciences: Theory \& Practice, 16(2), 691710. https://doi.org/10.12738/estp.2016.2.0257.

Bringula, R., Reguyal, J. J., Tan, D. D., \& Ulfa, S. (2021). Mathematics self-concept and challenges of learners in an online learning environment during COVID-19 pandemic. Smart Learning Environments, 8(1), 1-23. https://doi.org/10.1186/s40561-021$\underline{00168-5}$. 
Chevalier, A., \& Lanot, G. (2002). The relative effect of family characteristics and financial situation on educational achievement. Education Economics, 10(2),

165-181.

https://doi.org/10.1080/09645290210126904.

Christenson, S. L. (2004). The family-school partnership: An opportunity to promote the learning competence of all students. School psychology review, 33(1), 83-104. https://doi.org/10.1080/02796015.2004.12086233.

Ersan, O., Rodriguez, M.C. Socioeconomic status and beyond: a multilevel analysis of TIMSS mathematics achievement given student and school context in Turkey. Large-scale Assess Educ. 8, 15 (2020). https://doi.org/10.1186/s40536-02000093-y.

Kalaycığlu, D.B. (2015). The influence of socioeconomic status, self-efficacy, and anxiety on mathematics achievement in England, Greece, Hong Kong, the Netherlands, Turkey, and the USA. Kuram ve Uygulamada Egitim Bilimleri, 15(5), 1391-1401.

https://doi.org/10.12738/estp.2015.5.2731.

Nwagwu, W. E. (2020). E-learning readiness of universities in Nigeria-what are the opinions of the academic staff of Nigeria's premier university. Education and Information Technologies, 25(2), 13431370. https://doi.org/10.1007/s10639-019-10026-0.

Pillay, H., Irving, K., \& Tones, M. (2007). Validation of the diagnostic tool for assessing tertiary students' readiness for online learning. Higher Education Research \& Development, 26(2), 217-234. https://doi.org/10.1080/07294360701310821.

Riyanto, Y. (2011). Metodologi Penelitian Kualitatif $\mathcal{E}$ Kuantitatif. Surabaya: UNIPRESS.

Saryono, A. (2010). Metode Penelitian Kualitatif. Bandung: Alfabeta.

Slameto, S. (2003). Belajar dan faktor-faktor yang mempengaruhinya, Jakarta: Rineka Cipta.

Subagia, I. W., \& Wiratma, I. G. (2016). Profil penilaian hasil belajar siswa berdasarkan kurikulum 2013. JPI (Jurnal Pendidikan Indonesia), 5(1), 39-55. http://dx.doi.org/10.23887/jpiundiksha.v5i1.8293.

Syafa'ati, J. S. N., Sucipto, S., \& Roysa, M. (2021). Analisis Prestasi Belajar Siswa Pada Pembelajaran Daring di Masa Pandemi COVID-19. Jurnal Educatio FKIP UNMA, 7(1), 122-128. https://doi.org/10.31949/educatio.v7i1.882.

Tomul, E., \& Savasci, H. S. (2012). Socioeconomic determinants of academic achievement. Educational Assessment, Evaluation and Accountability, 24(3), 175-187. https://doi.org/10.1007/s11092-012-9149-3.
Tomul, E., Önder, E. \& Taslidere, E. (2021). The relative effect of student, family and school-related factors on math achievement by location of the school. Large-scale Assess Educ. 9(22) https://doi.org/10.1186/s40536-021-00117-1.

Umar, M. (2015). Peranan orang tua dalam peningkatan prestasi belajar anak. Jurnal Edukasi: Jurnal Bimbingan Konseling, 1(1), 20-28. http://dx.doi.org/10.22373/je.v1i1.315.

Winkel, WS. (2004). Psikolog Pendidikan dan Evaluasi Belajar. Jakarta: Gramedia.

Wiradarma, K. S., Suarni, N. K., \& Renda, N. T. (2021). Analisis Hubungan Minat Belajar terhadap Hasil Belajar Daring IPA Siswa Kelas III Sekolah Dasar. MIMBAR PGSD Undiksha, 9(3). http://dx.doi.org/10.23887/jipgsd.v9i3.39212.

Yamamoto, Y., \& Holloway, S. D. (2010). Parental expectations and children's academic performance in sociocultural context. Educational Psychology Review, 22(3), 189-214. https://doi.org/10.1007\%2Fs10648-010-9121-z. 